\title{
B-type peptides to predict post-liver transplant mortality: systematic review and meta-analysis
}

\author{
Daljeet Chahal MD' ${ }^{10}$, Alan Yau MD², Paola Casciato MD³, Vladimir Marquez MD²
}

\begin{abstract}
BACKGROUND: Cirrhotic patients undergoing liver transplantation are at risk of cardiac complications. Brain natriuretic peptide (BNP) and amino terminal brain natriuretic peptide (NT-BNP) are used in cardiac risk stratification. Their significance in predicting mortality risk in cirrhotic patients during or after liver transplantation is unknown. We conducted a systematic review and meta-analysis to answer this question. METHODS: An electronic search of EMBASE, MEDLINE, Cochrane Central Register of Controlled Trials, Cochrane Database of Systematic Reviews (2005-September 2016), Google Scholar, and study bibliographies was conducted. Study quality was determined, and demographic and outcome data were gathered. Random effects meta-analyses of mortality-based BNP and NT-BNP level or presence of post-transplant heart failure were conducted. RESULTS: Seven studies including 2,010 patients were identified. Demographics were similar between patients with high or low BNP or NT-BNP levels. Hepatitis C was the most prevalent etiology of cirrhosis (38\%). Meta-analysis revealed a pooled relative risk of 3.1 (95\% $\mathrm{Cl} 1.9 \%$ to $5.0 \%)$ for post-transplant mortality based on elevated BNP or NT-BNP level. Meta-analysis also revealed a pooled relative risk of $1.6(95 \% \mathrm{Cl} 1.3 \%$ to $2.1 \%)$ for post-transplant mortality if patients had demonstrated posttransplant heart failure. CONCLUSIONS: Our analysis suggests that BNP or NT-BNP measurement may help in risk stratification and provides data on post-operative mortality in cirrhotic patients undergoing liver transplantation. Discriminatory thresholds are higher in cirrhotic patients relative to prior studies with non-cirrhotic patients. However, the number of analyzed studies is limited, and our findings should be validated further through larger, prospective studies.
\end{abstract}

KEYWORDS: BNP; cardiovascular events; liver transplant; meta-analysis; systematic review

\section{Author Affiliation}

${ }^{1}$ Postgraduate Medicine Program, University of British Columbia, Vancouver, British Columbia; ${ }^{2}$ Division of Gastroenterology, University of British Columbia, Vancouver, British Columbia; ${ }^{3}$ Hospital Italiano, Buenos Aires, Argentina

Correspondence: Dr. Daljeet Chahal, Division of Gastroenterology, University of British Columbia, 5153-2775 Laurel Street, Vancouver, British Columbia V5Z 1M9. Telephone: 604-875-5618 ext 2. Fax: 604-875-5373. E-mail: daljeetc@alumni.ubc.ca 


\section{INTRODUCTION}

Cirrhotic patients undergoing liver transplantation are at high risk of death from cardiac complications even in the absence of any known underlying cardiac disease $(1,2)$. In a national database study, major adverse cardiac events (MACE) occurred in $11 \%$ of liver transplant recipients and had a negative impact on survival (3). Peri-transplant heart failure and myocardial depression have also been found to correlate with increased post-operative morbidity and mortality (4-6). High-risk features for MACE include pre-transplant atrial fibrillation and stroke (3). Regardless, algorithms or biomarkers commonly used for peri-operative risk stratification in other populations and surgical settings have not been thoroughly investigated in cirrhotic patients and liver transplantation.

Brain natriuretic peptide (BNP) and amino terminal brain natriuretic peptide (NT-BNP) are biomarkers commonly used in the management of congestive heart failure (7). In cirrhotic patients, elevated BNP or NT-BNP may reflect systolic dysfunction, left ventricular hypertrophy with subsequent diastolic dysfunction, and increased pulmonary artery pressures with resulting right ventricular overload $(8,9,10,12)$. Elevated BNP or NT-BNP also seems to reflect disease severity, with correlations to presence of ascites, decreased synthetic function, increased hepatic venous presence gradient, and increased Child-Pugh and model for end-stage liver disease (MELD) scores (13). Elevated BNP or NT-BNP has also been implicated as an independent predictor of mortality in advanced cirrhosis (14). This cardiac dysfunction in cirrhotic patients has been termed cirrhotic cardiomyopathy (CCM), although its clinical significance remains unknown (15). It has been suggested that because of CCM, large increases in cardiac pre-load such as that experienced upon perfusion of a newly transplanted liver, predisposes these patients to cardiac events and subsequent mortality even in the absence of other cardiac disease (16).

Elevated levels of pre-operative BNP or NTBNP are commonly used to risk stratify patients and predict cardiac events or mortality after both cardiac and non-cardiac surgery (20). However, as mentioned earlier, cirrhotic patients with CCM may demonstrate falsely elevated BNP or NT-BNP levels. Cirrhotic patients also display high rates of other comorbidities that may elevate BNP levels such as hyper-dynamic circulation, renal impairment, hypoxemia, and sepsis (17). Falsely elevated levels of cardiac biomarkers may not correlate with peri-operative risk (18). Alternatively, BNP levels in cirrhotic patients may be falsely low because of the prevalent use of diuretic medications such as spironolactone (19). Previous systematic reviews and meta-analyses of BNP or NT-BNP use for risk stratification have not included large numbers of cirrhotic patients or studies involving liver transplantation $(20,21)$. Therefore, the clinical measurement of pre-operative BNP or NT-BNP in the setting of cirrhosis and liver transplantation remains difficult to interpret.

We conducted a systematic review and metaanalysis to understand whether these commonly used biomarkers could have application in predicting peri- and post-liver transplant mortality or cardiovascular morbidity in cirrhotic patients. In addition, we wanted to define whether the presence of cirrhosis and associated comorbidities altered the clinical utility of these tests in this population.

\section{METHODS}

An electronic search of EMBASE (1974-September 2016), MEDLINE (1946-present), EBM ReviewsCochrane Central Register of Controlled Trials (1946-August 2016), EBM Reviews-Cochrane Database of Systematic Reviews (2005-September 2016), and Google Scholar was conducted. We also searched bibliographies of relevant studies and the 'related articles' link to identify studies that may have been missed in database searches. The search strategy was planned with the help of a medical librarian. Medical subject headings and free-text terms included combinations of 'brain natriuretic peptide,' 'b-type peptide,' 'natriuretic peptide, brain,' 'bnp,' 'nt-bnp,' 'ntprobnp,' 'probnp,' 'liver transplantation,' and 'liver transplant.'

The titles of all articles were assessed for relevance to the study question, and relevant articles were retrieved and abstracts screened in detail. The articles whose abstracts were pertinent were further evaluated. Our primary outcomes of interest were peri- and post-transplant all-cause mortality. Our secondary outcome of interest was peri- and post-transplant cardiovascular complications. We included studies that provided peri-operative data 
on NT-proBNP or BNP levels of cirrhotic patients, stratified cirrhotic patients into groups on the basis of the presence of elevated BNP or post-transplant heart failure, and provided post-transplantation outcome data on these cirrhotic cohorts. We excluded studies of children (aged younger than 19 years), non-human experiments, studies of multi-organ transplants, case reports, and studies that did not provide adequate BNP, NT-BNP, or outcome data. Both screening of identified studies and assessment for eligibility were performed in duplicate by two investigators (DC, AY) independently. Any disagreement between investigators was resolved by consensus.

Data were extracted independently by two investigators into a Microsoft Excel spreadsheet (Microsoft, Redmond, WA). The following data were extracted: year of publication, study design, number of patients included, baseline patient demographics, MELD and Child-Pugh scores immediately before transplant, cirrhosis etiology, cirrhosis complications, comorbidities, medications used, laboratory parameters, hemodynamic parameters, and echocardiographic data. Post-transplant data included mortality, cardiac events, and other complications of interest. When the data were not available from the article, we made an effort to email the authors directly for additional information. In case of nonresponse, an additional reminder email was sent. The quality of the studies was assessed using the Newcastle-Ottawa scale for observational studies with high-quality studies scoring above 6 (22).

For patient demographics, we calculated weighted means and standard deviations when applicable. For each study we calculated the incidence death rate or the incidence rate (IR) of cardiovascular complications after liver transplantation. We obtained the incidence relative risk (IRR) and 95\% confidence interval by comparing groups with high versus low pre-treatment BNP or NT-BNP values.

Heterogeneity between studies was assessed by using the $\mathrm{I}^{2}$ statistic with a cut-off value of $50 \%$ and the chi-square test with a $P$-value less than 0.10 to define a significant degree of heterogeneity. Before analysis, we decided that a meta-analysis using a random-effects model was going to be used in the absence of significant heterogeneity. In the presence of significant heterogeneity, individual study results would have been presented, but we would not pool their effects. Evidence of publication bias was assessed by applying the Egger test to funnel plots. All statistical analyses were performed using Stata 14.2 (StataCorp, College Station, Texas)

\section{RESULTS}

Our search yielded 192 records. After removal of duplicates, we were left with 177 records to screen. We ultimately excluded 147 records, leading to 30 full-text reviews. Of these 30, 7 articles met all criteria and were used for both qualitative and quantitative analysis (Figure 1).

\section{Study characteristics}

We identified seven studies for analysis (23-29). Four of these studies were prospective and three were retrospective in nature. All studies were single centre. Studies stratified their patient cohorts in one of two manners: either by a high BNP-NT-BNP versus a low BNP-NT-BNP or by the development of post-transplant heart failure versus no development of post-transplant heart failure. Sample sizes ranged from 40 to 970 patients. The majority of patients were transplanted for underlying cirrhosis. Study characteristics are detailed in Table 1. One study excluded patients with prior history of non-cirrhotic cardiac disease (29). Primary outcomes consisted of either mortality or development of heart failure or other cardiac events (heart failure, myocardial infarction, cardiac arrest, life-threatening arrhythmia). Follow-up times ranged from 6 months to more than 5 years. Assessment of quality by NewcastleOttawa Scale demonstrated scores of 7 or 8 for all studies (Table 2). Specifics of inclusion and exclusion criteria and outcomes may be found in Supplementary Table 1.

\section{Patient demographics}

A total of 2,010 patients were identified. Of these patients, 335 belonged to high BNP-NT-BNP or heart-failure cohorts (218 high BNP, 117 heart failure), whereas 1,675 belonged to low BNP-NTBNP or no-heart-failure cohorts (731 low BNP, 944 no heart failure). Studies reported statistics in both means and medians, and as such care was taken to record data as presented and make appropriate calculations. Weighted mean patient age was 52.5 (SD 9.3) years. Weighted mean BMI was 25.4 (SD 1.9). The proportion of male patients ranged from $51.5 \%$ to $81.3 \%$ and was similar between cohorts in all studies. Weighted mean MELD score for all patients was 18.5 (SD 2.3). 


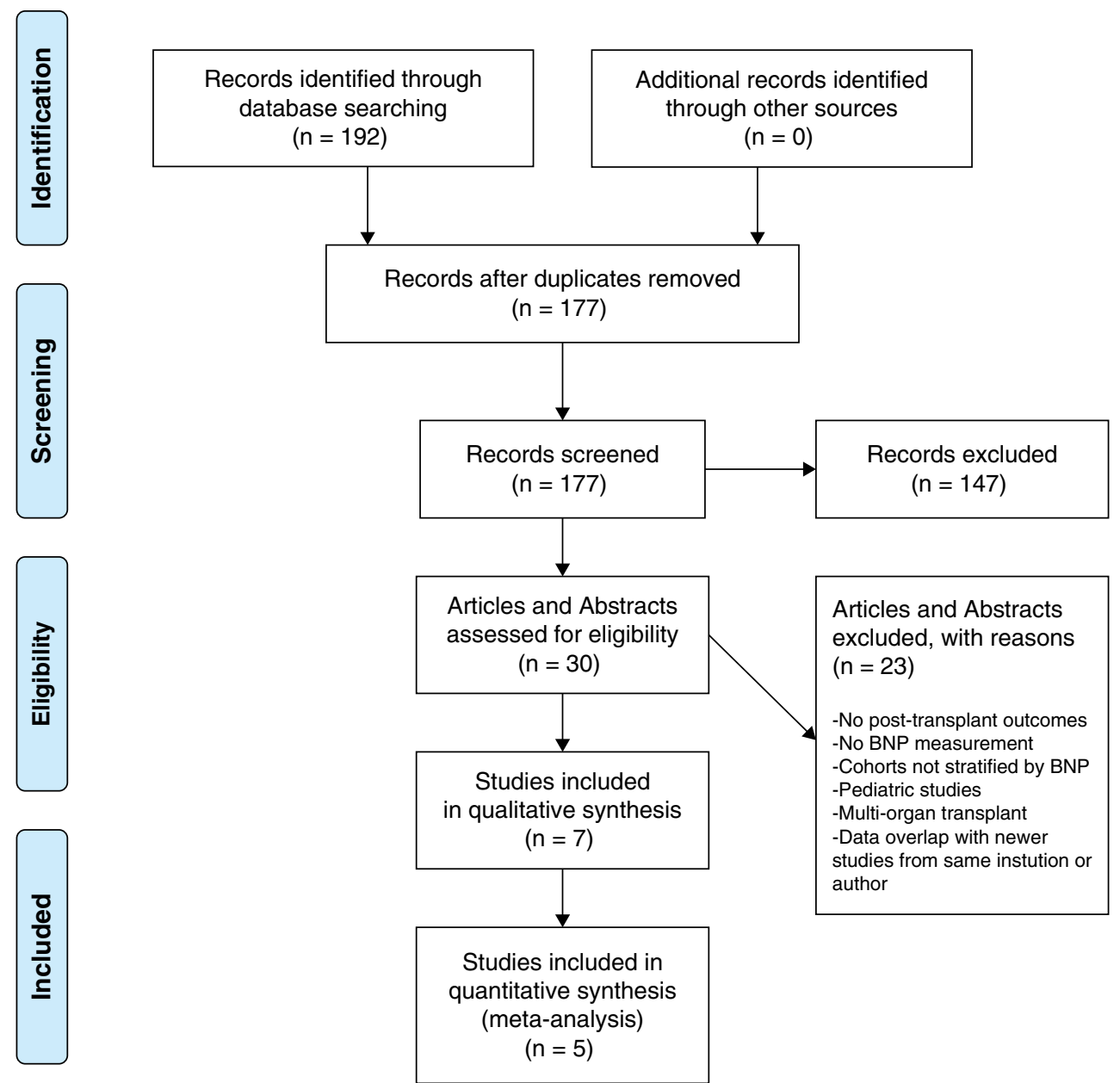

Figure 1: Results of systematic review search algorithm

Etiology of underlying cirrhosis was reported in six studies (Table 3 ). Hepatitis $C$ was the most prevalent etiology of cirrhosis (38\%). Other prevalent etiologies included alcohol (23\%), hepatocellular carcinoma $(7 \%)$, and non-alcoholic steatohepatitis (NASH; 5\%). There were 694 patients on diuretics and 439 on aldosterone. Specifics about patient demographics and medication use can be found in the supplementary data (Supplementary Table 2).

\section{BNP and NT-BNP measurements}

One study measured NT-BNP (29), and the remainder measured BNP levels (23-28). Five studies recorded pre-transplant BNP-NT-BNP levels, one recorded intra-operative levels, and one recorded levels on post-operative day 1 . Studies by Toussaint et al, Kim et al, and Saner et al stratified patient cohorts by BNP-NT-BNP levels $(23,25,27)$. Toussaint et al and Kim et al determined the optimal BNP level that predicted 180-day intensive care unit
(ICU) and 1-year mortality, respectively, by receiver operating characteristic curve with areas under curve of $0.79(0.66-0.93)$ and $0.694(0.652-0.733 ; 23$, 25). Saner et al pre-specified BNP values of less than $391 \mathrm{pg} / \mathrm{mL}$ and more than $391 \mathrm{pg} / \mathrm{mL}$ on the basis of prior experimental evidence suggesting that levels less than $391 \mathrm{pg} / \mathrm{mL}$ effectively ruled out heart failure (30). Studies by Qureshi et al and Casciato et al stratified patient cohorts on the basis of presence of heart failure $(24,26)$. Pre-operative BNP levels were higher in groups that developed heart failure in both the Qureshi et al study (120.3 [SD 139.3] $\mathrm{pg} / \mathrm{mL}$ versus $61.5[\mathrm{SD} 68.4] \mathrm{pg} / \mathrm{mL} ; P<0.001)$ and Casciato et al study (598.3 [interquartile range $\{\mathrm{IQR}\}$ 366.7] $\mathrm{pg} / \mathrm{mL}$ versus 115.0 [IQR 103.5] pg/mL; $P<0.001)$. The study by Therapondos et al stratified patients on the basis of presence of postoperative pulmonary edema and noticed higher pre-operative BNP levels in those who developed edema (75 [SD 24] vs. 42 [SD 6] pg/mL; $P<0.043 ; 28$ ). The study by Bernal et al did not directly compare 
D Chahal, A Yau, P Casciato, V Marquez

Table 1: Characteristics of studies included in meta-analysis

\begin{tabular}{|c|c|c|c|c|c|c|c|c|}
\hline Author & Year & Study type & $\begin{array}{l}\text { Study } \\
\text { period }\end{array}$ & $\begin{array}{l}\text { BNP/NT-BNP } \\
\text { measurement }\end{array}$ & Cohorts & $\begin{array}{l}\text { Patients, } \\
\mathrm{N}\end{array}$ & $\begin{array}{l}\text { Follow-up } \\
\text { time }\end{array}$ & Study outcomes \\
\hline $\begin{array}{l}\text { Toussaint } \\
\text { et al } \\
(23)\end{array}$ & 2016 & Prospective & $\begin{array}{l}2011- \\
2014\end{array}$ & $\begin{array}{l}\text { Pre-liver } \\
\text { transplant }\end{array}$ & $\begin{array}{l}\text { ICU survivors } \\
\text { vs. ICU } \\
\text { non-survivors } \\
\text { BNP }>155 \text { vs. BNP } \\
<155^{\dagger}\end{array}$ & 207 & $\begin{array}{l}6 \text { mo post- } \\
\text { transplant }\end{array}$ & $\begin{array}{l}\text { ICU mortality } \\
180 \text {-day mortality }\end{array}$ \\
\hline $\begin{array}{l}\text { Qureshi } \\
\text { et al } \\
(24)\end{array}$ & 2013 & Retrospective & $\begin{array}{r}2000- \\
2010\end{array}$ & $\begin{array}{l}\text { Pre-liver } \\
\text { transplant }\end{array}$ & $\begin{array}{l}\text { Heart failure vs. } \\
\text { no heart failure } \\
\text { post-OLT }\end{array}$ & 970 & $\begin{array}{l}\text { Mean } 5.3 \\
(\text { SD 3.4) } \\
\text { years }\end{array}$ & $\begin{array}{l}\text { Overall mortality } \\
\text { New-onset heart } \\
\text { failure } \\
\text { Cardiovascular } \\
\text { events }\end{array}$ \\
\hline $\begin{array}{c}\text { Kim et al } \\
(25)\end{array}$ & 2011 & Retrospective & $\begin{array}{r}2007- \\
2009\end{array}$ & $\begin{array}{l}\text { Intra- } \\
\text { operative }\end{array}$ & $\begin{array}{l}1 \text { y survivors vs. } 1 \text { y } \\
\text { non-survivors } \\
\text { BNP }<136 \text { vs. BNP } \\
>136^{+}\end{array}$ & 525 & $\begin{array}{l}1 \text { y post- } \\
\text { transplant }\end{array}$ & 1 y mortality ${ }^{\ddagger}$ \\
\hline $\begin{array}{l}\text { Casciato } \\
\text { et al } \\
(26)\end{array}$ & 2012 & Prospective & $\begin{array}{r}2009- \\
2011\end{array}$ & $\begin{array}{l}\text { Pre-liver } \\
\text { transplant }\end{array}$ & $\begin{array}{l}\text { Heart failure vs. } \\
\text { no heart failure } \\
\text { post-OLT }\end{array}$ & 51 & $\begin{array}{l}6 \text { mo post- } \\
\text { transplant }\end{array}$ & $\begin{array}{l}\text { Overall mortality } \\
\text { New-onset heart } \\
\text { failure } \\
\text { Cardiovascular } \\
\text { events }\end{array}$ \\
\hline $\begin{array}{l}\text { Saner } \\
\text { et al } \\
(27)\end{array}$ & 2011 & Retrospective & $\begin{array}{r}2008- \\
2009\end{array}$ & POD1 & $\begin{array}{l}\text { POD1 BNP < } 391 \text { vs. } \\
\text { POD1 BNP > 391 } \\
\text { POD1 BNP 391-567 } \\
\text { vs. POD1 BNP > } \\
567\end{array}$ & 157 & NR & $\begin{array}{l}\text { Overall mortality } \\
\text { Cardiovascular } \\
\text { events }\end{array}$ \\
\hline $\begin{array}{l}\text { Therapon- } \\
\text { dos } \\
\text { et al } \\
(28)\end{array}$ & 2002 & $\begin{array}{l}\text { Randomized } \\
\text { clinical trial }\end{array}$ & $\begin{array}{r}1996- \\
1998\end{array}$ & $\begin{array}{l}\text { Pre-liver } \\
\text { transplant }\end{array}$ & $\begin{array}{l}\text { Tacrolimus vs. } \\
\text { cyclosporine } \\
\text { post-OLT } \\
\text { Pulmonary edema } \\
\text { vs. no pulmonary } \\
\text { edema }{ }^{\dagger}\end{array}$ & 40 & $\begin{array}{r}\text { Median } \\
57 \mathrm{mo}\end{array}$ & $\begin{array}{l}\text { Overall mortality } \\
\text { Heart failure }\end{array}$ \\
\hline $\begin{array}{c}\text { Bernal et } \\
\text { al (29) }\end{array}$ & 2012 & Retrospective & $\begin{array}{r}2002- \\
2007\end{array}$ & $\begin{array}{l}\text { Pre-liver } \\
\text { transplant }\end{array}$ & $\begin{array}{l}\text { Cirrhotics vs. } \\
\text { non-cirrhotics* } \\
\text { BNP }>2,000 \text { vs. } \\
\text { BNP }<2,000^{+}\end{array}$ & 60 & $\begin{array}{l}\text { Mean } 69 \\
\quad(S D 26 \mathrm{mo})\end{array}$ & $\begin{array}{l}\text { Overall mortality } \\
\text { Cardiovascular } \\
\text { events }\end{array}$ \\
\hline
\end{tabular}

*Non-cirrhotic patients in this study were not transplanted

${ }^{\dagger}$ Cohorts used in meta-analysis

${ }^{\ddagger}$ Outcomes used in meta-analysis

Abbreviations: $B N P=$ brain natriuretic peptide; $I C U$ = intensive care unit; $N R=$ not reported; NT-BNP = amino terminal brain natri-

uretic peptide; $\mathrm{OLT}=$ orthotopic liver transplant; $P O D=$ post-operative day

different cohorts of cirrhotic patients; rather, they noticed higher pre-operative NT-BNP levels in cirrhotic patients than in healthy controls with no history of liver disease $(1,759$ (SD 1,154) pg/mL versus 856 (SD 123) $\mathrm{pg} / \mathrm{mL} ; P<0.05 ; 29$ ). In a sub-group, the study by Bernal noted more postoperative cardiac events in a group that exhibited NT-BNP levels higher than 2,000 pg/mL (specifics of cardiac events are detailed in the next section). The determination of the $2,000 \mathrm{pg} / \mathrm{mL}$ cut-off value was made on the basis of European Society of Cardiology guidelines that provide evidence that a NT-BNP value of more than $2,000 \mathrm{pg} / \mathrm{mL}$ in the presence of clinical signs and symptoms of heart failure is strongly suggestive of chronic heart failure (31). Specifics of BNP-NT-BNP levels in 
Table 2: New-Castle Ottawa Scale Assessment of Study Quality

\begin{tabular}{|c|c|c|c|c|c|c|c|c|}
\hline Quality Criteria & Acceptable & $\begin{array}{l}\text { Toussaint } \\
\text { et al (23) }\end{array}$ & $\begin{array}{l}\text { Qureshi } \\
\text { et al (24) }\end{array}$ & $\begin{array}{l}\text { Kim et } \\
\text { al (25) }\end{array}$ & $\begin{array}{l}\text { Casciato } \\
\text { et al (26) }\end{array}$ & $\begin{array}{l}\text { Saner } \\
\text { et al (27) }\end{array}$ & $\begin{array}{l}\text { Therapondos } \\
\text { et al (28) }\end{array}$ & $\begin{array}{l}\text { Bernal } \\
\text { et al (29) }\end{array}$ \\
\hline $\begin{array}{l}\text { Representativeness } \\
\text { of exposed cohort? }\end{array}$ & $\begin{array}{l}\text { Cirrhotic, increased } \\
\text { BNP, transplanted }\end{array}$ & $x$ & $x$ & $x$ & $x$ & $x$ & $x$ & $x$ \\
\hline $\begin{array}{l}\text { Selection of non- } \\
\text { exposed cohort? }\end{array}$ & $\begin{array}{l}\text { Cirrhotic, normal } \\
\text { BNP, transplanted }\end{array}$ & $x$ & $x$ & $x$ & $x$ & $x$ & $x$ & $x$ \\
\hline $\begin{array}{l}\text { Ascertainment of } \\
\text { exposure? }\end{array}$ & Secured records & $x$ & $x$ & $x$ & $x$ & $x$ & $x$ & $x$ \\
\hline $\begin{array}{l}\text { Outcome of inter- } \\
\text { est not present at } \\
\text { study start? }\end{array}$ & Alive at study start & $x$ & $x$ & $x$ & $x$ & $x$ & $x$ & $x$ \\
\hline $\begin{array}{l}\text { Study controls for } \\
\text { age and sex? }\end{array}$ & & $x$ & & $x$ & $x$ & $x$ & & \\
\hline $\begin{array}{l}\text { Study controls for } \\
\text { MELD score? }\end{array}$ & & & $x$ & & & & & \\
\hline $\begin{array}{c}\text { Assessment of } \\
\text { outcome? }\end{array}$ & $\begin{array}{l}\text { Independent blind } \\
\text { assessment, record } \\
\text { linkage }\end{array}$ & $x$ & $x$ & $x$ & $x$ & $x$ & $x$ & $x$ \\
\hline $\begin{array}{l}\text { Follow-up length } \\
\text { appropriate? }\end{array}$ & & $x$ & $x$ & $x$ & $x$ & & $x$ & $x$ \\
\hline $\begin{array}{l}\text { Adequacy of } \\
\text { follow-up }\end{array}$ & $\begin{array}{l}\text { Complete follow-up } \\
\text { or }<10 \% \text { lost }\end{array}$ & $x$ & $x$ & $x$ & $x$ & $x$ & $x$ & $x$ \\
\hline Total score & & 8 & 8 & 8 & 8 & 7 & 7 & 7 \\
\hline
\end{tabular}

Abbreviations: $B N P=$ brain natriuretic peptide; $M E L D=$ model for end-stage liver disease

cohorts, determination of cut-off values, and definitions of heart failure may be found in Supplementary Tables 3-5.

\section{Mortality}

Five of the seven studies reported mortality data based on BNP-NT-BNP level (Table 4). In the study by Toussaint et al, $17.8 \%$ of patients with BNP levels more than $155 \mathrm{pg} / \mathrm{mL}$ died by 6 months compared with $3.7 \%$ with BNP less than $155 \mathrm{pg} / \mathrm{mL}$ (23). In patients with a MELD score more than 25, 29.3\% of patients with BNP more than $155 \mathrm{pg} / \mathrm{mL}$ died at 6 months compared with only $6.7 \%$ with BNP levels less than $155 \mathrm{pg} / \mathrm{mL}$. Of patients with BNP levels more than $155 \mathrm{pg} / \mathrm{mL}, 15.1 \%$ died in the ICU during the immediate post-operative period compared with $14.9 \%$ with BNP less than $155 \mathrm{pg} / \mathrm{mL}$. Similarly, in those with a MELD score more than 25, 26.8\% with BNP more than $155 \mathrm{pg} / \mathrm{mL}$ died in the ICU compared with $0.0 \%$ with BNP less than $155 \mathrm{pg} / \mathrm{mL}$. In this study, each $50 \mathrm{pg} / \mathrm{mL}$ increase in BNP, after adjustment for MELD score, was associated with significant hazard ratios of
Table 3: Etiology of cirrhosis

\begin{tabular}{lc} 
Etiology & Percentage \\
\hline Alcoholic & 23 \\
Non-alcoholic steatohepatitis & 5 \\
Hepatitis C & 38 \\
Hepatitis B & 4 \\
Hepatocellular carcinoma & 7 \\
Biliary disease & 1 \\
Autoimmune disease & 2 \\
Primary biliary cirrhosis & 3 \\
Primary sclerosing cholangitis & 4 \\
Cryptogenic or other & 13 \\
\hline
\end{tabular}

1.035 for both ICU and 6-month mortality (1.0221.049; $P<0.001)$. In the study by Saner et al, $52.0 \%$ of patients with BNP levels more than $391 \mathrm{pg} / \mathrm{mL}$ died in hospital compared with $15.2 \%$ with BNP less than $391 \mathrm{pg} / \mathrm{mL}$ (27). In the study by Kim et al, $23.5 \%$ of patients with BNP more than $136 \mathrm{pg} / \mathrm{mL}$ 
D Chahal, A Yau, P Casciato, V Marquez

Table 4: Mortality events by study and cohort

\begin{tabular}{|c|c|c|c|c|}
\hline Study and cohort & Patients, $n$ & Mortality, no. of patients & Incidence, \% & Follow-up time \\
\hline \multicolumn{5}{|l|}{ Toussaint et al (23) } \\
\hline $\mathrm{BNP}>155$ & 73 & 13 & 17.8 & $6 \mathrm{mo}$ \\
\hline $\mathrm{BNP}<155$ & 134 & 5 & 3.7 & \\
\hline \multicolumn{5}{|l|}{ Saner et al (27) } \\
\hline $\mathrm{BNP}>391$ & 25 & 13 & 52.0 & In hospital \\
\hline $\mathrm{BNP}<391$ & 132 & 20 & 15.2 & \\
\hline \multicolumn{5}{|l|}{ Kim et al (25) } \\
\hline $\mathrm{BNP}>136$ & 102 & 24 & $23 \cdot 5$ & $1 \mathrm{y}$ \\
\hline $\mathrm{BNP}<136$ & 423 & 25 & $5 \cdot 9$ & \\
\hline \multicolumn{5}{|l|}{ Casciato et al (26) } \\
\hline Post-op HF & 11 & 1 & 9.1 & $6 \mathrm{mo}$ \\
\hline No post-op HF & 40 & 2 & 5.0 & \\
\hline \multicolumn{5}{|l|}{ Qureshi et al (24) } \\
\hline Post-op HF & 98 & 42 & 42.9 & $5.3(\mathrm{SD} 3.4) \mathrm{y}$ \\
\hline No post-op HF & 872 & 228 & 26.1 & \\
\hline \multicolumn{5}{|l|}{ Totals: } \\
\hline High BNP & 200 & 50 & 25.0 & \\
\hline Low BNP & 689 & 50 & $7 \cdot 3$ & \\
\hline Post-op HF & 109 & 43 & 39.4 & \\
\hline No post-op HF & 912 & 230 & 25.2 & \\
\hline
\end{tabular}

Note: BNP measured in $\mathrm{pg} / \mathrm{mL}$

Abbreviations: $\mathrm{BNP}=$ brain natriuretic peptide; $\mathrm{HF}$ = heart failure; post-op = post-operative

died at 1 year compared with $5.9 \%$ with BNP less than $136 \mathrm{pg} / \mathrm{mL}$ (25). LogBNP was associated with a significant 1-year all-cause mortality hazard ratio of $2.657(P<0.001)$. In the study by Casciato et al, $9.1 \%$ of patients who developed post-operative heart failure died at 6 months compared with $5.0 \%$ who did not develop post-operative heart failure (26). In the study by Qureshi et al, 42.9\% of patients who developed post-operative heart failure died compared with $26.1 \%$ who did not develop post-operative heart failure (24).

We tallied mortality events by studies that provided BNP-NT-BNP or heart failure cohorts. Examining studies that separated their cohorts on the basis of high or low BNP-NT-BNP, we found a total of 50 mortality events for 200 patients $(25.0 \%)$ who had high BNP-NT-BNP compared with 50 mortality events for 689 patients (7.3\%) who had low BNP-NTBNP. When examining studies that separated their cohorts on the basis of presence of post-operative heart failure, we found a total of 43 mortality events for the 109 patients $(39.4 \%)$ who developed postoperative heart failure compared with 230 mortality events for the 912 patients (25.2\%) who did not develop post-operative heart failure (Table 3 ).

We then performed two meta-analyses. The first analysis consisted of three studies that stratified cohorts into high BNP-NT-BNP versus low BNP-NT-BNP groups with the outcome of interest being all-cause mortality $(23,25,27$; Figure 2). A pooled IRR of 3.1 (95\% CI $1.9 \%$ to $5.0 \%$ ) was demonstrated. Heterogeneity did not preclude pooling (chi-square $P=0.179 ; \mathrm{I}^{2}=41.9 \%$ ). The second analysis consisted of two studies that stratified cohorts into presence of post-transplant heart failure versus no post-transplant heart failure with all-cause mortality as the outcome of interest (24, 26; Figure 3). A pooled IRR of 1.6 (95\% CI 1.3\% to $2.1 \%)$ was demonstrated. Heterogeneity did not preclude pooling (chi-square $P=0.930, \mathrm{I}^{2}=0.0 \%$ ). 
B-type peptides to predict post-liver transplant mortality

Study

ID
Events, $\quad$ Events, $\%$

Treatment Control Weight
Toussaint_2016

Kim_2011

Saner_2011

Overall (I-squared $=41.9 \%, p=0.179)$

NOTE: Weights are from random effects analysis
$\operatorname{RR}(95 \% \mathrm{Cl})$

$1.42(0.53,3.82)$

$13 / 134$

$5 / 73$

18.55

$3.98(2.37,6.67)$

$24 / 102$

$25 / 423$

42.04

$3.43(1.98,5.96) \quad 13 / 25 \quad 20 / 132 \quad 39.40$

$3.10(1.90,5.05) \quad 50 / 261 \quad 50 / 628 \quad 100.00$

Figure 2: Meta-analysis of post-operative mortality based on peri-operative BNP level

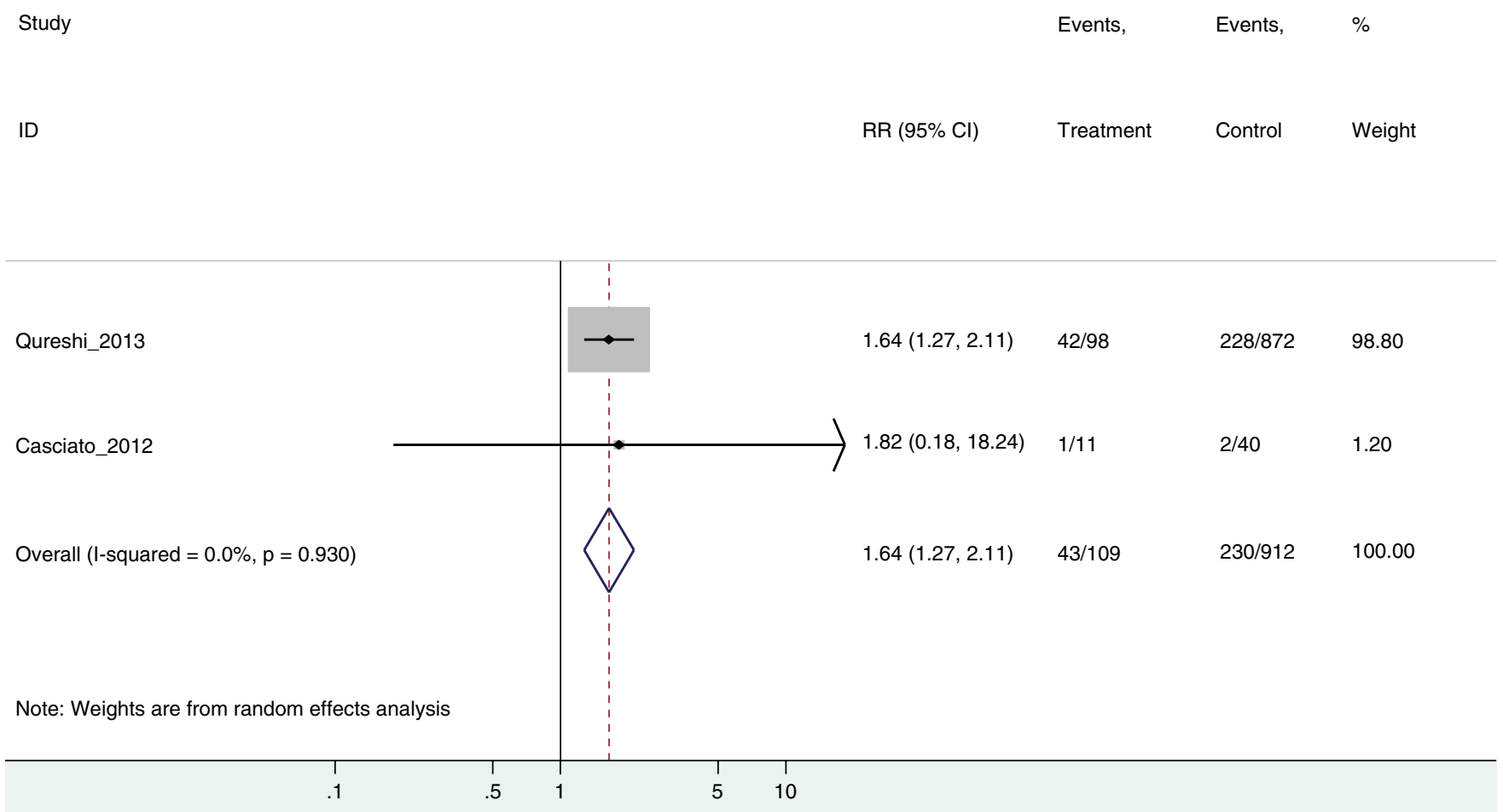

Figure 3: Meta-analysis of post-operative mortality based on presence of post-transplant heart failure 
Given the small number of studies included in this meta-analysis, assessment of publication bias by funnel plot and Egger's test was not appropriate.

\section{Post-operative cardiac events}

Five studies reported on post-operative heart failure, cardiac events, or both. Therapondos et al reported the development of pulmonary edema in 8 of 40 patients undergoing liver transplantation and noted that those with pulmonary edema had higher preoperative BNP levels, as mentioned earlier (28). Studies by Casciato et al and Qureshi et al noted higher BNP levels in those who developed post-operative heart failure, as noted above in the BNP and NT-BNP measurements section $(24,26)$. Qureshi et al reported that BNP more than $50 \mathrm{pg} / \mathrm{mL}$ was associated with development of post-operative systolic heart failure (hazard ratio [HR] 2.04 [95\% CI 1.21\% to 3.70\%]; $P=$ 0.02 ; 24) but not with post-operative diastolic heart failure (HR 1.01 [ $95 \%$ CI $0.42 \%$ to $2.43 \%$ ]; $P=0.98$ ). Qureshi et al. also noted six intra-operative cardiac arrests; five of these patients developed systolic dysfunction over a period of 5 years; only one patient developed immediate post-operative systolic failure. Intra-operative cardiac arrest was significantly associated with development of post-operative systolic heart failure (HR 16.39 [95\% CI $4.32 \%$ to $62.5 \%$ ]; $P<$ 0.001 ). Casciato et al, after adjusting for blood pressure, left ventricular ejection fraction, and left atrial diameter, also reported a significant association of elevated pre-operative BNP with development of postoperative acute heart failure (HR 1.95 [95\% CI 1.13\% to 3.34]; $P=0.016$ ).

Saner et al noted two post-operative incidences of cardiogenic shock in a subset of patients who had BNP greater than $567 \mathrm{pg} / \mathrm{mL}$ but none in those with BNP less than $567 \mathrm{pg} / \mathrm{mL}$ (27). Bernal et al noted that $37 \%$ of patients with NT-BNP greater than $2,000 \mathrm{pg} / \mathrm{mL}$ developed a non-specified cardiac event compared with $9 \%$ of those with BNP less than $2,000 \mathrm{pg} / \mathrm{mL}(P=0.008 ; 29)$. We calculated an IRR of $7.9(95 \%$ CI $1.8 \%$ to $34.7 \% ; P=0.006)$ for post-transplant cardiac events on the basis of elevated BNP from that study. Because of heterogeneity of reporting methods and patient stratification for post-operative cardiac events, a complete metaanalysis could not be carried out.

\section{DISCUSSION}

Liver transplantation a carries high a risk of post-operative MACE and mortality. BNP and
pre-NT-BNP are commonly assessed in preoperative settings to help stratify cardiac risk, but specific analysis in liver transplantation remains sparse. There is also concern that BNP or NT-BNP elevation in cirrhotic patients as a result of CCM or other comorbidities may not truly reflect post-operative risk. Although the number of studies in this analysis are limited, our results suggest that despite these concerns, BNP or NT-BNP measurement may be a viable method to identify those individuals at higher risk of mortality after liver transplantation.

\section{B-type natriuretic peptides, mortality, and cardiac events}

Meta-analysis of three studies demonstrated increased risk of death on the basis of elevated perioperative BNP or NT-BNP (IRR 3.1 [95\% CI 1.9\% to $5.0 \%])(23,25,27)$. These findings are in agreement with previous analyses of B-type natriuretic peptides that associated pre-operative elevations with postoperative mortality in non-cardiac, cardiac, and vascular surgery $(20,21,32,33)$. It is important to note that the majority of studies included in these previous analyses examined mortality within 30 days of surgery, whereas our included studies tallied mortality at 180 days (23), 1 year (25), and early in hospital without a time frame (27). However, the analysis in vascular patients also included a subgroup analysis of two studies demonstrating an association of 180-day mortality with elevated pre-operative BNP (HR 3.31, 95\% CI 2.1\% to 5.24\%; 33-35). The metaanalysis of BNP in cardiac surgery patients also included several studies extending far beyond 30 days, with one of the included studies reporting outcomes at a mean follow-up of 4.3 years (32). A caveat must be taken into account: a longer time frame for mortality outcomes necessitates a lower BNP-NTBNP discriminatory threshold $(36,37)$.

We also performed a meta-analysis of two studies that demonstrated increased risk of death on the basis of post-transplant heart failure (IRR 1.6 [95\% CI $1.3 \%$ to $2.1 \%$ ]) $(24,26)$. Pre-operative BNP in both studies was significantly higher in those patients who developed post-operative heart failure (Qureshi et al, 120.3 [SD 139.3] pg/mL versus 61.5 [SD $68.4 \mathrm{pg} / \mathrm{mL}$ ]; $P<0.001$; Casciato et al, 598.3 [IQR 366.7] $\mathrm{pg} / \mathrm{mL}$ versus 115.0 [IQR 103.5] pg/mL; $P<0.001)$. Median time to onset of heart failure was 101.5 days in the Qureshi et al study, and 7 of the 11 patients who developed heart failure in the Casciato et al study presented within 14 days of transplant. This was a secondary outcome in 
our study, and we did not necessarily identify all studies that directly evaluated association of posttransplant heart failure with mortality. For example, a study not included in our analysis because of the lack of BNP data associated peri-transplant heart failure with peri-transplant mortality (OR 15.11 [95\% CI $1.76 \%$ to $129.62 \%$ ]) (5). Regardless, the elevation of pre-operative BNP in those who developed heart failure and its association with mortality again suggests the validity of risk stratification with BNP in cirrhotic patients undergoing liver transplantation.

Reporting of post-operative cardiac events in our included studies, excluding heart failure, was sparse. Only one study reported raw data specifically on elevated BNP and post-transplant cardiac events, with a calculated IRR of 7.9 (95\% CI 1.8\% to $34.7 \%$ ) (29). It is interesting that this study excluded patients with known cardiac disease, possibly implicating CCM in the development of post-operative events. There was also association of pre-operative BNP elevation with development of post-operative systolic heart failure (HR 2.04 [95\% CI $1.21 \%$ to $3.70 \%] ; P=0.02$ ) in the Qureshi et al study and post-operative acute heart failure (HR 1.95 [95\% CI $1.13 \%$ to $3.34 \%] ; P=0.016$ ) in the Casciato study $(24,26)$. These studies did not exclude patients with previous cardiac disease, and as such the etiology of their heart failure could be quite varied. Unfortunately, the lack of data specific to cardiac events does not allow us to comment on the association between peri-operative BNP-NT-BNP elevation and immediate post-operative events.

Taken together, these meta-analyses suggest that peri-operative elevations in BNP-NT-BNP are associated with increased risk of mortality in cirrhotic patients undergoing liver transplantation. It is possible that post-operative heart failure may serve as the primary driver of mortality. However, it is important to note that the number of studies in this area are quite limited, and they are varied in their methodology. Thus, rather than making firm conclusions, we suggest that our results are exploratory and should be further assessed through larger, prospective trials.

\section{Non-cardiac mechanisms for B-type peptide} alterations in cirrhotic patients

Falsely high levels of peri-operative natriuretic peptides unrelated to underlying cardiac disease may not necessarily reflect peri-operative risk (18). It is therefore important to understand why natriuretic peptides in cirrhotic patients may be elevated. Plasma levels of natriuretic peptides are elevated relative to healthy controls and are directly correlated with the extent of liver disease (38). Elevations are greater in patients with ascites, spontaneous bacterial peritonitis, and hepatic encephalopathy, again reflecting extent of cirrhosis (39). Correlations of peptide elevation and cirrhosis stage may reflect impaired ability of the cirrhotic liver to clear these peptides, although the exact contribution of hepatic clearance is unknown (40). Interestingly, individual studies in our analysis reported higher MELD scores in those with greater levels of BNP-NT-BNP, again suggesting the correlation of cirrhosis severity with biomarker elevation. It should be noted that patients with acute liver failure were excluded from most of our included studies, and the implications of peptide measurement in that population are unknown.

Biomarker elevations are also seen in sepsis, renal insufficiency, and pulmonary hypertension with implications for hepato-renal and hepatopulmonary syndrome (41). Studies in our analysis commented very infrequently on sepsis, renal insufficiency, or pulmonary disease, and we do not know whether these factors may have confounded peptide levels or mortality rates. Natriuretic peptide levels are also decreased by diuretic or aldosterone antagonist use, which a large number of cirrhotic patients use (19). A large number of patients in our analysis used diuretics, aldosterone antagonists, or both before to transplantation. Whether decreases in BNP-NT-BNP in patients on these medications confounded results of our analysis is again unknown and requires further investigation.

\section{Cardiac mechanisms for B-type peptide alterations in cirrhotic patients}

Traditional cardiac disease may also account for elevations in natriuretic peptides. Advances in care are leading to an older transplant population with a greater number of comorbidities, including ischemic cardiac disease (42). In addition, NASH is on track to become the most common indication for liver transplantation (43). Presence of NASH is associated with hyperlipidemia, hypertension, diabetes, and coronary artery disease $(44,45)$. Patients with NASH experience a greater number of adverse cardiac events than those without NASH, and this is likely attributable to underlying ischemic heart disease (46). In our analysis, NASH accounted for only $5 \%$ of transplant indications (Supplementary Tables 6-7). However, data on 
comorbid ischemic or non-ischemic heart disease were sparsely reported in our study population and could certainly have contributed to biomarker elevation. Ischemic and non-ischemic heart disease confer peri-operative risk and remain an essential component of the pre-liver transplant workup (47).

Last, CCM itself results in elevation of natriuretic peptides (2). Echocardiographic measurements demonstrate diastolic dysfunction and increased ventricular chamber thickness in those with CCM and biomarker elevation (10). A high frequency of cirrhotic patients display cardiac abnormalities such as cardiomegaly and left ventricular hypertrophy in autopsy studies (48). It is thought that splanchnic vasodilation leads to increases in cardiac output and heart rate, resulting in ventricular thickening and biomarker elevation (2). Indeed, BNP-NT-BNP levels are greater in cirrhotic patients who display systolic dysfunction and have a direct correlation with long-term survival (8). Whether or not CCM itself conveys perioperative risk is not established. In our analysis, only the study by Bernal et al excluded those with prior cardiac disease (29). Future studies that examine non-operative and operative outcomes in patients with CCM but no signs of other cardiac disease will help establish the clinical significance of this condition.

\section{Optimizing test parameters in cirrhotic patients} and liver transplantation

The use of BNP-NT-BNP as a pre-operative risk assessment tool has recently been introduced into the Canadian Cardiovascular Society's perioperative guidelines (49). This recommendation is largely based on one high-quality analysis (20). This analysis shows that a pre-operative BNP more than $92 \mathrm{pg} / \mathrm{mL}$ or NT-BNP more than $300 \mathrm{pg} / \mathrm{mL}$ in patients at elevated risk for cardiac disease (aged 65 years or older, Revised Cardiac Risk Index $\geq 1$, or ages 45-64 years with significant cardiovascular disease) effectively identified patients at higher risk for peri-operative cardiac events. These patients are then subsequently monitored with post-operative serial troponin measurements. An elevation in troponin may result in initiation of acetylsalicylic acid, a statin, and an angiotensin-converting enzyme inhibitor or angiotensin receptor blocker (49).

The analysis by Rodseth et al did not include any studies of liver transplantation, and the prevalence of cirrhotic patients was not reported (20). Whether the discriminatory thresholds calculated in that study are applicable to cirrhotic patients or liver transplantation is unknown. Discriminatory thresholds for BNP and NT-BNP in our included studies appear to be higher than those recommended in the Canadian Cardiovascular Society guidelines. This may reflect non-cardiac mechanisms of peptide elevation in cirrhotic patients. In addition, the study by Toussaint et al found that BNP values above or below the discriminatory threshold $(155 \mathrm{pg} / \mathrm{mL})$ were better at predicting ICU mortality or survival in those patients with a MELD score of more than 25 (23). Taken together, these data suggest that both optimization of discriminatory thresholds and addition of parameters unique to cirrhotic patients, such as MELD scores, will help to create a more reliable method of risk stratification for liver transplantation.

Role of cirrhotic cardiomyopathy in risk stratification

As discussed earlier, etiology of cardiac disease in cirrhotic patients includes traditional ischemic and non-ischemic heart disease but also CCM. The perioperative risk of traditional cardiac disease is well established, but the clinical significance of CCM remains debated. At the current time, the American Association for the Study of Liver Diseases practice guidelines and American Heart Association guidelines for kidney and liver transplant candidates recommend assessment for coronary artery disease before surgery, but neither make any mention of CCM $(47,50)$. Although increased rates of cardiac events in the cirrhotic population, even in the absence of known cardiac disease, argues for CCM as a significant entity, this must be confirmed through future studies.

\section{Limitations}

Limitations of this meta-analysis included that only a small number of studies were identified, varying BNP assays were used with different cut-offs and measurement timing in each study, and there was absence of complete clinically relevant information such as demographic and echocardiographic data

\section{CONCLUSION}

Our analysis suggests that early BNP measurement provides valuable data on post-operative mortality in patients undergoing liver transplantation. These data are in agreement with previous guidelines for other surgical procedures. Risk stratification may help with final organ allocation. 
However, it is important to note that this analysis included a limited number of studies with the limitations previously noted. Our results are exploratory and should be further assessed through larger, prospective trials. Future studies may also focus on optimization of BNP-NT-BNP discriminatory thresholds and addition of cirrhosis-unique parameters to risk scores (e.g., MELD).

CONTRIBUTIONS: Conceptualization, DC; Methodology, DC; Formal Analysis, DC, VM; investigation, DC, AY; Resources, DC; Data Curation, DC; Writing-Original Draft, DC, VM; Writing-Review and Editing, DC, AY, VM, PC.

FUNDING: No funding was received for this article. DISCLOSURES: The authors have no conflicts to declare.

\section{REFERENCES}

1. Henriksen JH, Gøtze JP, Fuglsang S, Christensen E, Bendtsen F, Møller S. Increased circulating pro-brain natriuretic peptide (proBNP) and brain natriuretic peptide (BNP) in patients with cirrhosis: relation to cardiovascular dysfunction and severity of disease. Gut. 2003;52(10):1511-7. https://doi.org/10.1136/ gut.52.10.1511. Medline: 12970147

2. Wiese S, Hove JD, Bendtsen F, Møller S. Cirrhotic cardiomyopathy: pathogenesis and clinical relevance. Nat Rev Gastroenterol Hepatol. 2014;11(3):177-86. https://doi.org/10.1038/ nrgastro.2013.210. Medline: 24217347

3. VanWagner LB, Serper M, Kang R, Levitsky J, Hohmann S, Abecassis M, et al. Factors associated with major adverse cardiovascular events after liver transplantation among a national sample. Am J Transplant. 2016;16(9):2684-94. https://doi.org/10.1111/ajt.13779. Medline: 26946333

4. Nasraway SA, Klein RD, Spanier TB, Rohrer RJ, Freeman RB, Rand WM, et al. Hemodynamic correlates of outcome in patients undergoing orthotopic liver transplantation. Chest. 1995;107(1):218-24. https://doi.org/10.1378/ chest.107.1.218. Medline: 7813282

5. Josefsson A, Fu M, Allayhari P, Björnsson E, Castedal $M$, Olausson $M$, et al. Impact of peri-transplant heart failure and leftventricular diastolic dysfunction on outcomes following liver transplantation. Liver Int.
2012;32(8):1262-9. https://doi.org/10.1111/ j.1478-3231.2012.02818.x. Medline: 22621679

6. Rahman S, Mallett SV. Cirrhotic cardiomyopathy: Implications for the perioperative management of liver transplant patients. World J Hepatol. 2015;7(3):507. https://doi. org/10.4254/wjh.v7.i3.507. Medline: 25848474

7. Oremus M, Don-Wauchope A, McKelvie R, Santaguida PL, Hill S, Balion C, et al. BNP and NT-proBNP as prognostic markers in persons with chronic stable heart failure. Heart Fail Rev. 2014;19(4):471-505. https://doi.org/10.1007/ s10741-014-9439-6. Medline: 24986335

8. Pimenta J, Paulo C, Gomes A, Silva S, Rocha-Gonçalves F, Bettencourt P. B-type natriuretic peptide is related to cardiac function and prognosis in hospitalized patients with decompensated cirrhosis. Liver Int. 2010;30(7):1059-66. https://doi.org/10.1111/ j.1478-3231.2010.02266.x. Medline: 20492497

9. Bernal V, Pascual I, Esquivias P, García-Gil A, Fernández C, Mateo JM, et al. Cardiac hemodynamic profiles and pro-B-type natriuretic peptide in cirrhotic patients undergoing liver transplantation. Transplant Proc. 2009;41(3):985-6. https://doi.org/10.1016/j. transproceed.2009.02.020. Medline: 19376404

10. Huh IY, Kim YK, Shin WJ, Park SE, Bang JY, Hwang GS. Increased B-type natriuretic peptide during liver transplantation: relationship to invasively measured hemodynamic parameters. Transplant Proc. 2012;44(5):1318-22. https:// doi.org/10.1016/j.transproceed.2012.01.140. Medline: 22664008

11. Bernal V, Pascual I, Esquivias P, García-Gil A, Mateo JM, Lacambra I, et al. N-terminal brain natriuretic peptide as a diagnostic test in cirrhotic patients with pulmonary arterial hypertension. Transplant Proc. 2009;41(3):987-8. https://doi.org/10.1016/j. transproceed.2009.02.025. Medline: 19376405

12. Kim YK, Seong SH, Jun IG, Chin JH, Sang BH, Park YS, et al. Preoperative echocardiographic indices associated with elevated brain natriuretic peptide in liver transplant recipients. Transplant Proc. 2011;43(5):1691-5. https:/ / doi.org/10.1016/j.transproceed. 2011.03.085. Medline: 21693259 
13. Espinosa M-D, Olmedo C, Muffak-Granero K, Comino A, Nogueras M-F, Villegas M-T, et al. Preoperative natriuretic peptide-B values and ascites in male liver transplant recipients. Transplant Proc. 2011;43(3):705-7. https:// doi.org/10.1016/j.transproceed.2011.01.086. Medline: 21486579

14. Karagiannakis DS, Vlachogiannakos J, Anastasiadis G, Vafiadis-Zouboulis I, Ladas SD. Diastolic cardiac dysfunction is a predictor of dismal prognosis in patients with liver cirrhosis. Hepatol Int. 2014;8(4):588-94. https:/ / doi.org/10.1007/s12072-014-9544-6. Medline: 26202764

15. ChayanupatkulM,LiangpunsakulS. Cirrhotic cardiomyopathy: review of pathophysiology and treatment. Hepatol Int. 2014;8(3): 308-15. https: / / doi.org/10.1007/s12072-0149531-y. Medline: 25221635

16. Myers RP, Lee SS. Cirrhotic cardiomyopathy and liver transplantation. Liver Transpl. 2000; 6(Suppl 1):S44-52. https:/ / doi.org/10.1002/ lt.500060510. Medline: 10915191

17. Ge PS, Runyon BA. Role of plasma BNP in patients with ascites: advantages and pitfalls. Hepatology.2014;59(3):751-3.https://doi.org/ 10.1002/hep.26689. Medline: 23959954

18. Goei D, Schouten O, Boersma E, Welten GMJM, Dunkelgrun $\mathrm{M}$, Lindemans J, et al. Influence of renal function on the usefulness of N-terminal pro-B-type natriuretic peptide as a prognostic cardiac risk marker in patients undergoing noncardiac vascular surgery. Am J Cardiol. 2008;101(1):122-6. https://doi.org/10.1016/j. amjcard.2007.07.058. Medline: 18157978

19. Tsutamoto T, Wada A, Maeda K, Mabuchi N, Hayashi M, Tsutsui T, et al. Effect of spironolactone on plasma brain natriuretic peptide and left ventricular remodeling in patients with congestive heart failure. J Am Coll Cardiol. 2001;37(5):1228-33. https:/ / doi. org/10.1016/S0735-1097(01)01116-0

20. Rodseth RN, Biccard BM, Le Manach Y, Sessler DI, Lurati Buse GA, Thabane L, et al. The prognostic value of pre-operative and postoperativeB-typenatriureticpeptidesinpatients undergoing noncardiac surgery. J Am Coll Cardiol. 2014;63(2):170-80. https://doi.org/ 10.1016/j.jacc.2013.08.1630. Medline: 24076282
21. Karthikeyan G, Moncur RA, Levine O, Heels-Ansdell D, Chan MTV, Alonso-Coello P, etal.Is a pre-operativebrain natriuretic peptide or N-terminal pro-B-type natriuretic peptide measurement an independent predictor of adverse cardiovascular outcomes within 30 days of noncardiac surgery? A systematic review and meta-analysis of observational studies. J Am Coll Cardiol. 2009;54(17):1599-606. https://doi.org/10.1016/j.jacc.2009.06.028. Medline: 19833258

22. Wells G, Shea B, O'ConnellD, Peterson J, Welch V, Losos M, Tugwell P. Newcastle-Ottawa Quality Assessment Scale cohort studies. http:/ / www. ohri.ca/programs / clinical_epidemiology / oxford.asp. (Accessed November 11, 2015).

23. Toussaint A, Weiss E, Khoy-Ear L, Janny S, Cohen J, Delefosse D, et al. Prognostic value of preoperative brain natriuretic peptide serum levels in liver transplantation. Transplantation. 2016;100(4):819-24. https://doi.org/10.1097/ TP.0000000000001077. Medline: 26845306

24. Qureshi W, Mittal C, Ahmad U, Alirhayim Z, Hassan S, Qureshi S, et al. Clinical predictors of post-liver transplant new-onset heart failure. Liver Transpl. 2013;19(7):701-10. https:/ / doi.org/10.1002/lt.23654 Medline: 23554120

25. Kim YK, Shin WJ, Song JG, Kim Y, Kim WJ, $\mathrm{Kim} \mathrm{SH}$, et al. Evaluation of intraoperative brain natriuretic peptide as a predictor of 1-year mortality after liver transplantation. Transplant Proc. 2011;43(5):1684-90. https:/ / doi.org/10.1016/j.transproceed.2011.02.010. Medline: 21693258

26. Casciato P, Arias A, Mariani M, Galdame O, de Santibanes E, Gadano A. Heart failure due to cirrhotic cardiomyopathy after liver transplantation. Unpublished work.

27. Saner FH, Neumann T, Canbay A, Treckmann JW, Hartmann M, Goerlinger K, et al. High brain-natriuretic peptide level predicts cirrhotic cardiomyopathy in liver transplant patients. Transpl Int. 2011;24(5):425-32. https: / / doi.org/10.1111/j.1432-2277.2011. 01219.x. Medline: 21276088

28. Therapondos G, Flapan AD, Dollinger MM, Garden OJ, Plevris JN, Hayes PC. Cardiac function after orthotopic liver transplantation and the effects of immunosuppression: a 
prospective randomized trial comparing cyclosporin (Neoral) and tacrolimus. Liver Transpl. 2002;8(8):690-700. https://doi.org/10.1053/ jlts.2002.34381. Medline: 12149762

29. Bernal V, Pascual I, Lanas A, Esquivias P, Piazuelo E, Garcia-Gil FA, et al. Cardiac function and aminoterminal pro-brain natriuretic peptide levels in liver-transplanted cirrhotic patients. Clinical Transplantation. 2012;26(1):111-6. https://doi.org/10.1111/ j.1399-0012.2011.01438.x. Medline: 21447142

30. Maisel AS, Koon J, Krishnaswamy P, Kazenegra R, Clopton P, Gardetto N, et al. Utility of B-natriuretic peptide as a rapid, point-of-care test for screening patients undergoing echocardiography to determine left ventricular dysfunction. Am Heart J. 2001;141(3):367-74. https:/ / doi.org/10.1067/ mhj.2001.113215. Medline: 11231433

31. Dickstein K, Cohen-Solal A, Filippatos G, McMurray JJV, Ponikowski P, Poole-Wilson PA, et al. ESC Guidelines for the diagnosis and treatment of acute and chronic heart failure 2008: the Task Force for the Diagnosis and Treatment of Acute and Chronic Heart Failure 2008 of the European Society of Cardiology. Eur Heart J. 2008;29(19):2388-442. https:/ / doi.org/10.1093/ eurheartj/ehn309. Medline: 18799522

32. Litton E, Ho KM. The use of pre-operative brain natriuretic peptides as a predictor of adverse outcomes after cardiac surgery: a systematic review and meta-analysis. Eur J Cardiothorac Surg. 2012;41(3):525-34. https: / / doi. org/10.1093/ejcts/ezr007. Medline: 22345176

33. Rodseth RN, Padayachee L, Biccard BM. A meta-analysis of the utility of pre-operative brain natriuretic peptide in predicting early and intermediate-term mortality and major adverse cardiac events in vascular surgical patients. Anaesthesia. 2008;63(11):1226-33. https://doi. org/10.1111/j.1365-2044.2008.05574.x. Medline: 18673363

34. Feringa $\mathrm{HHH}$, Schouten $\mathrm{O}$, Dunkelgrun $\mathrm{M}$, Bax JJ, Boersma E, Elhendy A, et al. Plasma $\mathrm{N}$-terminal pro-B-type natriuretic peptide as long-term prognostic marker after major vascular surgery. Heart. 2007;93(2):226-31. https: / / doi.org/10.1136/hrt.2006.093716. Medline: 16914484
35. Mahla E, Baumann A, Rehak P, Watzinger N, Vicenzi MN, Maier R, et al. N-terminal probrain natriuretic peptide identifies patients at high risk for adverse cardiac outcome after vascular surgery. Anesthes. 2007;106(6): 1088-95. https:/ / doi.org/10.1097/01.anes. 0000267591.34626.b0. Medline: 17525582

36. Cuthbertson $\mathrm{BH}$, Amiri AR, Croal BL, Rajagopalan S, Brittenden J, Hillis GS. Utility of B-type natriuretic peptide in predicting medium-term mortality in patients undergoing major non-cardiac surgery. Am J Cardiol. 2007;100(8):1310-3. https://doi.org/10.1016/j. amjcard.2007.05.058. Medline: 17920377

37. Berry C, Kingsmore D, Gibson S, Hole D, Morton JJ, Byrne D, et al. Predictive value of plasma brain natriuretic peptide for cardiac outcome after vascular surgery. Heart. 2006;92(3):401-2. https://doi.org/10.1136/hrt. 2005.060988. Medline: 16501204

38. La Villa G, Romanelli RG, Raggi VC, TostiGuerra C, De Feo ML, Marra F, et al. Plasma levels of brain natriuretic peptide in patients with cirrhosis. Hepatology. 1992;16(1):156-61. https: / / doi.org/10.1002/hep.1840160126. Medline: 1618467

39. Yildiz R, Yildirim B, Karincaoglu M, Harputluoglu M, Hilmioglu F. Brain natriuretic peptide and severity of disease in non-alcoholic cirrhotic patients. J Gastroenterol Hepatol. 2005;20(7):1115-20. https://doi.org/10.1111/ j.1440-1746.2005.03906.x. Medline: 15955223

40. Potter LR. Natriuretic peptide metabolism, clearance and degradation. FEBS J. 2011; 278(11):1808-17. https://doi.org/10.1111/j.17424658.2011.08082.x. Medline: 21375692

41. Leuchte HH, Nounou ME, Tuerpe JC, Hartmann B, Baumgartner RA, Vogeser M, et al. N-terminal pro-brain natriuretic peptide and renal insufficiency as predictors of mortality in pulmonary hypertension. Chest. 2007;131(2):402-9. https://doi.org/10.1378/ chest.06-1758. Medline: 17296640

42. Adam R, McMaster P, O'Grady JG, Castaing D, Klempnauer JL, Jamieson N, et al. Evolution of liver transplantation in Europe: Report of the European Liver Transplant Registry. Liver Transpl. 2003;9(12):1231-43. https://doi.org/ 10.1016/j.lts.2003.09.018. Medline: 14625822 
43. Charlton MR, Burns JM, Pedersen RA, Watt KD, Heimbach JK, Dierkhising RA. Frequency and outcomes of liver transplantation for nonalcoholic steatohepatitis in the United States. Gastroenterology. 2011;141(4):1249-53. https://doi.org/10.1053/j.gastro.2011.06.061. Medline: 21726509

44. Malik SM, DeVera ME, Fontes $\mathrm{P}$, Shaikh O, Ahmad J. Outcome after liver transplantation for NASH cirrhosis. Am J Transpl. 2009;9(4):782-93. https://doi.org/10.1111/j. 1600-6143.2009.02590.x. Medline: 19344467

45. Anstee QM, Targher G, Day CP. Progression of NAFLD to diabetes mellitus, cardiovascular disease or cirrhosis. Nat Rev Gastroenterol Hepatol. 2013;10(6):330. https://doi.org/10.1038/ nrgastro.2013.41. Medline: 23507799

46. Treeprasertsuk S, Lopez-Jimenez F, Lindor KD. Nonalcoholic fatty liver disease and the coronary artery disease. Dig Dis Sci. 2011;56(1):35-45. https: / / doi.org/10.1007/s10620-010-1241-2. Medline: 20464495

47. Murray KF, Carithers RL. AASLD practice guidelines: evaluation of the patient for liver transplantation. Hepatology. 2005;41(6): 1407-32.https://doi.org/10.1002/hep.20704. Medline: 15880505

48. Ortiz-Olvera NX, Castellanos-Pallares G, Gómez-Jiménez LM, Cabrera-Muñoz ML, Méndez-Navarro J, Morán-Villota S, et al. Anatomical cardiac alterations in liver cirrhosis: an autopsy study. Ann Hepatol. 2011;10(3):321-6. Medline: 21677334

49. Duceppe E, Parlow J, MacDonald P, Lyons K, McMullen M, Srinathan S, et al. Canadian Cardiovascular Society Guidelines on perioperative cardiac risk assessment and management for patients who undergo noncardiac surgery. Can J Cardiol. 2017;33(1):17-32. https:/ / doi.org/10.1016/j.cjca.2016.09.008. Medline: 27865641

50. Lentine KL, Costa SP, Weir MR, Robb JF, Fleisher LA, Kasiske BL, et al. Cardiac disease evaluation and management among kidney and liver transplantation candidates: a scientific statement from the American Heart Association and the American College of Cardiology Foundation. Circulation. 2012;126(5):617-63. https: / / doi.org/10.1161/ CIR.0b013e31823eb07a. Medline: 22753303 